\title{
Political Dynasty and Kinship Networking in Bantanese Pilkada
}

\author{
Suranto \\ Department of Governmental Studies, UMY \\ Yogyakarta, Indonesia \\ suranto@umy.ac.id \\ Tunjung Sulaksno \\ Department of Governmental Studies, UMY \\ Yogyakarta, Indonesia \\ mas_tunjung@yahoo.com
}

\author{
Awang Daru Murti \\ Department of Governmental Studies, UMY \\ Yogyakarta, Indonesia \\ awang.darumurti@yahoo.co.id \\ Titin Purwningsih \\ Department of Governmental Studies, UMY \\ Yogyakarta, Indonesia \\ titin_p_widodo@yahoo.com
}

\begin{abstract}
The phenomenon of proliferation of political practices of kinship networking in Indonesia in the reform era is potentially endanger democracy due to the different treatment for competing political actors opportunities, as well as undermine the party's internal mechanisms in recruiting candidates for public officials. The location of this research is in Banten Province, where the phenomenon of kinship is very massive happened. The aims of the research are to explore: (1) the history of political dynastic involvement in PILKADA (local head elections), (2) the factors drive the political dynasty actors to enter the political sphere; (3) the background of the political dynasties involved in the Pilkada; (4) the function of political party recruitment in Pilkada, and (5) the instruments are utilized by political dynasty's candidates in Pilkada. The type of the research is a qualitative, using FGD, interview, and documentation study for collecting data, which will be analyzed using triangulation method. The results show that democratization and decentralization policy have been the key point for the actors of political dynasty to involve. In addition, The mastery of the economic base became the main driver of the dynastic political actors, so that most of the actors were entrepreneurs, meanwhile the functions of the party in recruitment are ineffective. Finally, the instruments frequently used by the political dynasty actors are money politics, kinship networks, and the use of mass organizations as a means of voters mobilization.
\end{abstract}

\section{Keywords: Kinship Network, Political Dynasty, Pilkada, Banten}

\section{A. Background}

Elections are often positioned as the main precondition of democracy due to its close relationship. Obviously, there is no democratic country that does not run elections on a regular basis. Elections become links that help to realize the idea of Government of the people, by the people and for the people as the normative meaning of democracy. Not just as an arena to express the freedom of the people in electing their leaders, elections are also mechanism to appreciate the performance of leaders. Through elections, voters are able to assess whether the elected government and or elected representative institutions will be deserved to be re-elected or even need to be replaced due to their lack of capacity to execute the mandate of the people. No wonder if elections occupy a central position in a democratic order.

Unfortunately, in many consolidating democracies elections are often hijacked and used as instruments of personal and / or group interests. One of the phenomena that is often considered to plow democracy is the existence of dynastic politics or kinship network. If the former pure political dynasty depended particularly on the status of nobility and politics then the recent political dynasty plays over the arena of democracy. It proved that the dynasty was able to fight in any political weather. Political dynasty actors will continue to play in any political system because their glue is access to state resources. Dynasties can live in both authoritarian and democratic systems (Muhtadi, 2013).

Many political dynasties and kinship networks in Indonesia use the election to rule, as is the case in Banten and South Sulawesi. The facts above show that the political network of kinship will not be destroyed only because of legal regulation. Sociological and historical factors become important, especially since there will be other networks ready to replace the dynastic outcast. One thing that can guarantee a fair competition in politics (or business) is if the bureaucracy that guards the political selection process (or economy) is professional, transparent and accountable (Vishnu, 2013).

Pablo Querubin (2011: 2) defines the political dynasty as' a form of long elite mastery when a family or some monopolizes political power. Instead, he linked political dynasties in the Philippines in the framework of democracy, and so he criticized the policy of job restrictions that still had a gap for the political dynasty to remain in power. Querubin also attributed the continuity of political dynasties in the Philippines to the effects of incumbency. Various politically motivated killings in the Philippines witness how the political 
dynasty used various means to perpetuate its power by utilizing the existence of elections. Family descendants of politicians generally believe that public office is a birthright and is inherited (Tuazon, 2013). But in many countries the political dynasty is legalized through the election process.

The same phenomenon has also taken place in Indonesia. Some incumbents do everything to make themselves or their families elected in the democratic process, whether through the practice of money politics or by using state funds (pork barrels, patronage, and programmatic policies) to deceive the people. In the case of Banten, Indonesia Corruption Watch (ICW) revealed a fantastic increase in grants and Social Aid program ahead of the 2011 gubernatorial election.

Due to its destructive potentials to democracy, it would be crucial to conduct a research concerning the political dynasty in Banten, Indonesia. Banten is chosen to be research location since it represents a massive symptoms of family network involvement in Pilkada. The research is intended to explore how the pattern of political dynasty or kinship network in direct Pilkada in Banten Province as well as the ways used to obtain or maintain power.

\section{B. Research Questions} issues:

The research is intended to to answer five following

1. What is the history of political dynasties and kinship networks in the context of elections in Banten Province?

2. What is the background of the emergence of the political actors of dynasty or kinship network in Banten?

3. What are the factors behind the involvement of political actors of a political dynasty or kinship network?

4. What is the role of political parties in carrying out the recruitment / candidacy function in the diret Pilkada in Banten Province?

5. What are the instruments used by political actors from certain political dynasties or kinship networks to win elections?

\section{Conceptual Theory \\ 1. Political Dynasty Concept}

Political kinship or political dynasty occurs in many countries. In the United States for instance, in the period of 2003 - 2005, there were 55 out of 109 members of Congress are members of a political dynasty, and in the period 20052007, there were 25 out of 110 members of the senate are members of a political dynasty. According to Hess' research, there are more than 22 political dynasty in the United States. Meanwhile in the Philippines, more than $50 \%$ of the members of Congress and governors had relatives in political offices.

Hess (1966) posits a political dynasty as —any family that has had at least four members, in the same name, elected to federal office.These definitions are useful but unable to capture important variations that, based on this research's initial observations, may occur. Hess' strict definition of political dynasty is also problematic for several reasons. First, in many countries family name may not be a part of local tradition. For instance, in Indonesia, it is common that an individual has a single name, without a family name. Thus, many members of political dynasty do not share a family name with the dynasty 'founders. Secondly, Hess specifies that at least four members of the family must have been elected to various public positions. His definition is problematic since it does not capture variants of political dynasty that currently have fewer than four members who have succeeded in securing public office.

\section{The Origin of the Political Dynasty}

Several scholars have explained some reasons behind the emergence of political dynasty in a democratic society. By utilizing historical records from the U.S. Congress, Dal Bó et al. $(2009,116)$ argue that the period of an incumbent's occupying office is positively correlated with the probability of the creation of political dynasty of the incumbent's family. They argue that this phenomenon is an example of - power begets power. Their research is also supported and expanded by Feinstein (2010) on the electoral origins of American dynasty in Congress, Crowley and Reece (2013) on American governors; and Kurtz (1995) on the Justices of the U.S. and Louisiana Supreme Courts; and (2009) on Argentinian political dynasty. According to this group of scholars, the main reason behind dynastic politicians' success is their - brand name advantage ${ }^{1}$. Dynastic brand name advantage is not only beneficial for attracting voters, but it may also help dynastic politicians to occupy minor positions in their party organization, and their family name provides a wider access to financial contributors for their political campaigns ${ }^{2}$. Dynastic politicians also have greater opportunity to secure support from traditional informal groups that previously supported their predecessors ${ }^{3}$.

\section{Methodology}

The object of this research is the practice of governance and elections in Banten Province. The type of research is qualitative using data collection techniques through interviews, observation and Focus Group Discussion in addition to documentation. While the data analysis technique used is triangulation. Triangulation refers to the use of more than one approach to the investigation of a research question in order to enhance confidence in the ensuing findings. Since much social research is founded on the use of a single research method and as such may suffer from limitations associated with that method or from the specific application of it, triangulation offers the prospect of enhanced confidence.

${ }^{1}$ The root of these scholars" argument is prior works by Clubok et al. (1969); Hess (1966); Kurtz (1989); Lott Jr (1986)

${ }^{2}$ Crowley and Reece (2013). Feinstein (2010, pp. 585-589), however, rejects these hypotheses

${ }^{3}$ Asako et al. (2012); Dal Bó et al. (2009, pp. 116, 132); Ishibashi and Reed (1992); Kurtz (2001) 


\section{E. Result:}

\section{The History of Kinship Politics in Banten's Pilkada}

\section{Context}

Democratization practice in Indonesia in the context of Central-Regional Devolution policy after post New Order Era has two contradictive consequences. On one hand, decentralization process has relatively succeeded in bringing common goodness, such as public services quality improvement, proportional finance relationship between local and central government, massive infrastructure development and the emergence of innovative policy of governance. But on the other hand, there are also some negative impacts, which one of them is power abuse in form of corruption conducted by local head which are directly elected by society through Pilkada. Many public figures, both from executive and legislative institution have been arrested due to their power abuse.

The new Pilkada regulation has generated some new problems. One of the significant case is the emergence of local strongman $^{4}$ who became stowaway people. Consequently, elections has led to pessimism for many scholars that the deepening democracy and enhancement of civic engagement through elections may just be theoretically effective due to the destructive ways to the political order to gain or retain power

The local strongman phenomenon does not only arise in the process of democratization in Indonesia. More similar symptoms occur in Thailand. McVey in his study shows that local bosses have become part of Thai political life. Local strongmen phenomenon is not really a new item in Thailand. However, their existence strengthened by democratization in around 1973. Local strongman in Thailand can be recognized at least through their monopolistic nature in almost all economic activities. They are also indicated to be actively involved in illegal business such as narcotics trade, gambling and smuggling. They are respected for their ability to control the community through its coercive apparatus in the region ${ }^{5}$.

In Camaçari, Brazil, democratization encourages the emergence of clientelism among the economic and political elites, thus fueling acute ungovernability. The effect is very real. Regional finances are robbed by the economic and political elite in both the executive and the legislature. They manipulate the policymaking body to produce political decisions that benefit him and his cronies. The impact is not a bit of an economic boss and local strongman who later became a formal figure 6 .

${ }^{4}$ Local Strongman is a term introduced by Migdal in his study of phenomenaStrong local people in $3^{\text {rd }}$ world countries in the 1970s decade-in Migdal, Joe S. Migdal,Strong Societies and Weak State: State-Society Relations and State Capabilities in the Third World Princeton: Princeton University Press, 1988.

${ }^{5}$ Ruth McVey, R. (ed.). 2000. Money and Power in Provincial Thailand. Copenhagen : Nordic Institute of Asian Studies (NIAS).

${ }^{6}$ Scönleitner, G. 2004. Can Public Deliberation Democratise State Action?: Municipal Health Council And Local
But the local strongman phenomenon in Indonesia has a unique side when compared to in other countries. Local Strongman in Indonesia is greedy and self-enlarging. Although both strengthened its existence after the wave of democratization, but these powerful local people were not satisfied when they managed to gain political power for themselves. From time to time they seek to expand their influence and power by shaping a dynastic politics or political network of kinship by placing members of their family in public positions available and widely accessible through direct elections after the fall of the authoritarian and centralized political system.

One of the most powerful political dynasties that should be used as a reference when discussing dynastic politics or kinship politics in Indonesia is the Chasan Sochib family in Banten. This dynasty or kinship network is considered special in Bantanese politics after the New Order because it succeeded in placing a number of family members occupying important positions in the executive and legislative spheres both at the central and regional levels. The imprisonment of the two key figures in this family, Ratu Atut and his daughter Tubagus Chaeri Wardana (Wawan) who had been the key actors of the dynastic actions of Banten politics and economics did not necessarily undermine this dynasty. Noted dynasties are still able to get some victory in the election after both of them imprisoned. Andika, Atut's son, even managed to establish himself as the second person in Banten after his partner won the 2017 election against Rano Karno-Embay Mulya Syarif pair. Embay himself is a founding figure of Banten Province. The victory is also proving that Chasan Sochib dynasty is still taken into account.

Talking about the dynasty that for the people of Banten known as 'Rau Family' is certainly can not be separated from a figure named Haji Chasan Sochib, the father of Ratu Atut. Chasan Sochib was a Bantanese Jawara from Ciomas who, in the 1960s, began to enter the business world by trading rice. Already before the reform era, Chasan Sochib was known to be very close to both civilian and military elites. It is this proximity that makes him often get major construction projects especially from the government of West Java Province as well as logistics projects from Kodam VI Siliwangi at that time ${ }^{7}$.

Chasan Sochib then became a very influential person in Banten with his company, CV Sinar Ciomas, which later transformed into PT Sinar Ciomas Raya. Chamber of Commerce and Industry (KADIN) Banten, Gapensi Banten, Construction Services Development Agency (LPJK) Banten, and numbers of other business organizations are mastered by

Democracy In Brazil. in.John Harriss, Kristian Stokke, \& Olle Tornquist. (eds.) Politicing Democracy: The Local Politics Of Democratisation. New York: Palgrave Macmillan. Pp.. 75-106.

${ }^{7}$ CNN Indonesia, KPK Nilai Politik Dinasti Muluskan Potensi Korupsi,

http://www.m.cnnindonesia.com/politik/20150709162515-32$\underline{65522}$, July 9, 2015 
him. Furthermore, through a Banten scholar named Haji Mahmud, Chasan Sochib began to get acquainted with the political world by becoming activists and administrators of the Golkar party ${ }^{8}$. On an occasion of after successfully delivering Atut to be a Vice-Governor of Banten in 2002, Chasan Sochib even claimed that he was the 'Governor General' reflecting the magnitude of his influence in the most western province of Java $^{9}$

In the reform era, there is a trend to demand of new local government formation (pemekaran). The people of Banten also began to demand a separated province, apart from the province of West Java. There was a fear from Chasan Sochib that the separation of Banten from West Java will disrupt his business. But when the wind of demands of the establishment of the Banten province increasingly strong, then Chasan Sochib changed direction. From what was opposed to the efforts of the establishment of this new province became known as one of the founders of Banten province ${ }^{10}$. When Banten succeeded in becoming a new autonomous region, Chasan Sochib encouraged his daughter, Ratu Atut, to plunge into politics by pairing Atut with Djoko Munandar. The effort was fruitful with the success of the couple became Governor and Vice Governor of Banten 2002-2007 through an election by members of the Banten Provincial DPRD (local house of representatives) in 2001.

The election was described as intimidating, where the houses of Banten DPRD members was guarded by Jawara, the subordinates of Chasan Sochib. Not only in the house, the Jawara also gave psychological pressure to the members of the DPRD by entering the courtroom. ${ }^{11}$. Jawara also controls the developing opinion with two strategies. First, by buying media people to defend their interests; And secondly, repressing uncooperative media people by violent means. ${ }^{12}$. After three years of being vice Governor in Banten, Atut promoted to be Governor in charge, because Djoko Munandar, the governor, is caught by KPK in a corruption case

Around 2004, the reins of this dynastic leadership began to shift to Chasan Sochib's son from his first wife, Tb. Chaeri Wardana or commonly called Wawan ${ }^{13}$. Wawan to this day has never been directly involved in politics by becoming a regional head or a member of the legislature. Yet it was Wawan who became a determinant person in this family, who determined the business and political strategy of the Rau

${ }^{8}$ Ali Nurdin, in the FGD, Politik Kekerabatan dan Dinasti Politik dalam Pemilihan Gubernur Banten, Universitas Mathla'ul Anwar Banten, July 29, 2017at Universitas Mathla'ul Anwar, Pandeglang, Banten, Juli 29, 2017.

${ }^{9}$ https://m.tempo.co/read/news/2013/10/07/063519657/silsilah -dinasti-banten-abah-chasan-dan-para-istri/3

${ }^{10}$ Ibid.

${ }^{11}$ Abdul Hamid, Memetakan Aktor Politik Lokal Banten Pasca Orde Baru: Studi Kasus Kiai dan Jawara di Banten, in POLITIKA Jurnal Ilmu Politik vol 1 No. 2, Oktober 2010, p. 4.

12 Ibid.

${ }^{13}$ Ali Nurdin. op.cit.
Family. Wawan determines the family members whom to be fight in the elections. Lobby with political parties is also a matter of Wawan ${ }^{14}$. Determination of government officials such as the head of Dinas (local office) must also be through the approval of Wawan. This monopoly on economy and politics in the hands of this family makes the clan of Chasan Sochib very strong in Banten.

In 2007, Atut advanced to the nomination of governors in direct elections. Atut paired with Mohammad Masduki managed to occupy the post of Governor of Banten period 2007-2012. Atut who then paired with Rano Karno also managed to win the 2011 elections of Banten so that back into the Governor of Banten period 2012-2017. After becoming the governor of Banten, Atut had large opportunities to put his family into the realm of practical politics, just as his father did. In the same year, Atut's brother, Tubagus Haerul Jaman, was elected as Vice Mayor of Serang, Banten, accompanying Bunyamin. But three years later, on March 25, 2011, Haerul rose to mayor of Serang by replacing Bunyamin who died. Haerul then re-elected mayor of Serang for 2013-2018 period. Atut's half brother, Ratu Lilis Karyawati, strengthens the political network and secures the interests of this family from the party line with his success as Chairman of DPD II Golkar Serang City during 2009-2014.

In 2010, Atut one mother's sister, Ratu Tatu Chasanah, was elected Vice Regent of Serang accompanying Taufik Nuriman for 2010-2015 period. Ratu Tatu also managed to become Chairman of DPD I Golkar Party of Banten on December 27, 2013 in Musdalub Golkar Party, replacing his brother-in-law who is also the husband of Ratu Atut, Hikmat Tomet who died. His career as a politician increased after in the Serang district elections held in December 2015, Ratu Tatu successfully elected as Regent of Serang for 2016-2021 period paired with H. Pandji Tirtayasa. Atut's stepmother or Chasan Sochib's wife, Heryani, was elected as Vice Regent of Pandeglang in 2011 to accompany Erwan Kurtubi. While Atut's other stepmother or Chasan Sochib's sixth wife, Ratna Komalasari, was elected to Serang City Council Member 2009-2014 period.

The success of the regent or mayor in the province of Banten applies not only to his wife and a direct descendant Chasan Sochib, but also to indirect descendants. Sister in law of Atut, Airin Rachmi Diany, the wife of Tubagus Chaeri Wardana, had to run for vice-regent of Tangerang accompany Jazuli Juwaini in 2008. Although at the time she was lost to the incumbent Ismet Iskandar and Rano Karno, but Airin Rachmy Diani paired with Benyamin Davnie eventually went on to become mayor of South Tangerang in the elections of 2011. In December 2015 election, Airin again won the elections and became the mayor of South Tangerang South Tangerang 2016-2021 period. Atut's another brother in law, namely Aden Abdul Kholik is also husband of Ratu Lilis became a member Banten Parliament of 2009-2014 period. But in the middle of the way his political career stalled. Aden dismissed and was replaced as a result of his indiciplinary acts

${ }^{14}$ Ali Nurdin. op.cit 
for violating the party line to run in the regent election of Tangerang from another party ${ }^{15}$.

Not only in the local scope of Banten, Atut's family also even expanded into the national political scene. The late husband of Atut, Hikmat Tomet who died on 9 November 2013, is a member of House Commission V of the period 2009-2014. Atut's son, Andika Hazrumy, also managed to become a member of DPD RI period 2009-2014. After that Andika also became a member of Parliament of the period 2014-2019. However, before his tenure in the House of Representatives, Andika decided to fight for the seat of Banten regional head in 2017 by becoming a representative of Wahidin Halim who previously also a member of the House of Representatives. Atut's son-in-law, Ade Rossi Khairunnisa who is also Andika's wife helped strengthen the Atut clan network in the political arena of Banten by serving as Vice Speaker of Serang DPRD 2009-2014 and in the period 20142019 succeeded in becoming a member of Banten Regional House of Representatives. Ade Rossi was then appointed Vice Chairman of the DPRD Banten in 2016.

The number of Atut relatives who occupy positions in the executive and legislative body both at the district, provincial, and central levels is not separated from the large number of descendants of Chasan Sochib own pretty much obtained from some wives whose numbers are no one knows. Wasiah, Chasan Sochib's first wife confessed to Tempo that Hasan Sochib himself was not sure how many children he had and the names of all his children. However, based on the Supreme Court letter obtained by Tempo, Chasan Sochib has 25 heirs of six wives ${ }^{16}$

The kinship network not only controls the public positions as described in the table above, but the network is booming because it covers political parties, especially Golkar Party, strategic organizations and interest groups in Banten region including business association, organization of sports and youth, religious organizations, and socio-cultural organizations that have a meaning for the people of Banten as illustrated in the table below

Because of the control of Chasan Sochib's family and relatives in Golkar Party starting from the district / city, provincial and central levels, it becomes very easy to understand why in almost every election in Banten the Chasan Sochib family can easily get access to involved in with the Golkar flag. This further reinforces the allegation that political parties have been instrumental in building political dynasties. Political parties today have a tendency to include party cadres who have strong capital. The average political dynasty has a strong capital that allows it to win in electoral battles, even though it does not have sufficient capacity

The party is considered to have a role in building this dynasty because in the process of recruiting the cadres who

${ }^{15}$ http://www.m.tempo.co/amphtml/read/news/2012/12/06/083 446198/zaki-iskandar-calon-bupati-tangerang-paling-kaya ${ }^{16}$ https://m.tempo.co/read/news/2013/10/07/063519657/silsila h-dinasti-banten-abah-chasan-dan-paraistri/3 actually have strong ability and integrity, tend not to ogled because of the lack of capital they have ${ }^{17}$. Capital in the form of money, popularity, and the extent of the organization network owned by the Chasan Sochib family became one of the extraordinary bargaining power for Golkar Party in Banten region to carry the candidate from this family, besides the party's party structure control by this family. As a result, the party's internal mechanisms in the recruitment of candidates who will occupy public positions tend not to work as they should. Ineffective party recruitment mechanism is also recognized by a member of KPU Pandeglang. Act Number 2 Year 2011 on Political Parties actually requires political parties to play the role of education and regeneration. However, the tendency of the party is closed in its recruitment pattern. The average party candidates are those who economically established, not the result of a serious recruitment process ${ }^{18}$

Although traditionally the 'Rau Family' is entrusting its political legitimacy through the Golkar Party, it is actually trying to secure their interests by maintaining political support from parties other than Golkar Party. Any party that will organize an activity and need financing will come to Atut's family usually will be supported so that the party feels a debt to this family, ${ }^{19}$, which in any event can serve as a 'check' to withdraw support from the political parties against the interests 'Rau Family'.

One thing that is rarely known, Atut's big family also uses modern political strategy despite effective control the Golkar Party of Banten, and put many members of his family in mass organizations in Banten. Before and during the Pilkada fight, families employed political consultants, and trusted how popular they were or how electable they were by conducting surveys. They also use political marketing techniques to convince people to vote for them ${ }^{20}$

Although not as big as Chasan Sochib clan, Banten also has other political dynasties. One of them is located in Lebak District, that is the Jayabaya family. The dynastic plunge into politics was preceded by the election of Mulyadi Jayabaya, the head of the family, the regent of Lebak for two periods, during 2003-2013. Not enough ten years to become regent of Lebak, Mulyadi then passed the throne of Lebak to his daughter, $\mathrm{Hj}$. Iti Octavia Jayabaya who succeeded in winning Lebak Election and became Regent of the 2014-2019 period. The Jayabaya family also grew stronger when Mulyadi's son Mochamad Hasbi Asyidiki Jayabaya was elected to the House of Representatives for the period 2014-2019. The other Mulyadi's daughter, Diana Dramawati Jayabaya, succeeded in becoming a member of Banten Regional House of

17 Dahnil Anzar Simanjuntak, interviewed by Kompas at http://nasional.kompas.com/read/2013/10/14/2134587/

Partai.Politik.Punya.Peran.Ciptakan.Dinasti.Politik

${ }^{18}$ FGD Result, Politik Kekerabatan dan Dinasti Politik dalam Pemilihan Gubernur Banten, Universitas Mathla'ul Anwar Banten, July 29, 2017

${ }^{19}$ Ali Nurdin. op.cit.

${ }^{20}$ Ali Nurdin. op.cit. 
Representatives for the period 2014-2019. In addition, his younger sister, Mulyanah, was elected to become member of Lebak's DPRD during 2009-2014. Mulyanah's Husband, Agus R. Wisas, became a member of the DPRD Banten for the period of 2009-2014. In the last elections of 2014, he failed to become a member of the House of Representatives. The nephew of Jayabaya, Vivi Sumantri Jayabaya, also managed to become a member of the House of Representatives for the period of 2014-2019.

Similarly, Jayabaya family is also active in several mass organizations and political parties in Lebak District and Banten Province level. Mulyadi for example, became chairman of KADIN Banten period 2015-2020 to replace his brother who died, Sumantri Jayabaya. As for Mochamad Hasbi known as Chairman of KONI of Lebak Regency for 2010-2014 tenure.

One thing that distinguishes the two families is in its relation to political parties. The Jayabaya family is relatively flexible and pragmatic in party affairs. The Jayabaya family does not only exist in one party as the Chasan Sochib family that relies on the Golkar Party to gain its political legitimacy. Mulyadi himself is the Head of the of Lebak District PDIP Branch Office, the party that supports him twice becomes the Lebak regent. While his younger brother, Sumantri Jayabaya had been the general treasurer of the Lebak Regency Golkar Branh Office.

His children are also not in the same political vehicle. Before becoming Regent of Lebak, Iti was a member of the House of Representatives from the Democratic Party. Currently, she is the Chairman of Democratic Party of Lebak District. When progressing in Lebak Pilkada 2013, Iti also supported by the Democratic Party. While his brother, Hasbi, became a member of the House through the PDIP. Their cousin, Vivi Sumantri also became a member of the House of Representatives by carrying the Democratic Party.

Despite being a PDIP officer of Lebak District, but in 2017 Banten Gubernariate Election, Mulyadi actually had time to support Wahidin Halim-Andika pair that carried Golkar, Democrat, Hanura, PKS, PAN, PKB and Gerindra Party instead of Rano Karno-Embay Syarif whom supported by PDIP. Nevertheless, about 4 months before the election, Mulyadi made a maneuver in politics by reiterating the support of the couple who carried by PDIP. This political choice is different from other Jayabaya family members such as his sister, Sumantri Jayabaya or even his daughter, Iti Octavia who in the 2017 election gave support to the couple of Wahidin Halim-Andika whom carried by Golkar. Mulyadi's choice to support Rano Karno-Embay is similar to his son's choice, Hasbi. Although in some different election news it shows the outbreak of the Jayabaya dynasty, but there is also the possibility that the maneuver shows a two-leg political game performed by the Jayabaya family. Whoever wins the Jayabaya family remains in a politically secure position

\section{Background of the Emerge of the Political Kinship Actors}

There are two reasons of the emergence of political dynasty or kinship network in the Banten pilkada, first, due to the opening of access to enter politics as a result of democratization and decentralization that significantly alter the pattern of relations between the center and the regions. This is what is called as political opportunity.

Secondly, the emergence of political dynasties in the regions of the concolidating democracies is motivated primarily by the ability of the incumbent dynastic politicians to create an uneven playing field by exploiting their kinship networks and materials to seek victory for family members ${ }^{21}$

\section{Factors Behind The Involvement Of Political Actors From A Political Dynasty Or Kinship Network}

There are two main factors, First, the socio-cultural factors associated with Banten's epidemic are highly characterized by patron-client relationship patterns. Secondly, the low factor of public education and the lack of social control over the regional head. It is being a common knowledge that the education level of the Banten people is the lowest among the six provinces in Java. The educated population is very low, so the middle-class function should be able to exercise low social control. Research conducted by Fatih (2016) shows that there are 3 categories of society seen from the tendency of political attitudes, namely: 1 . A pragmatic society that is central to the countryside. Kyai is no longer a culture broker but a political broker. 2. Apathy community spread in urban areas 3 . Enlightened society that comes from pragmatists and apathy.

\section{Cadre Process of Political Parties}

In the era of Liberal Democracy, political parties have a very significant role due to they are the only organization that formally to be contestants in the Pilkada. Political parties are expected to present their ideological cadres so that ideological cadre is expected to run well internally within the Political Parties.

However, political party actually shows the failure of ideological cadre. Instead of being driven by ideological interests, political parties are in fact are more driven by survival efforts and the need to continue in the flow of power, using pragmatic means, for which even the "ideological migration" or displacement of ideological attitudes though. From the study, Ambardi then concluded the phenomenon as a political cartel with the character of a party system that is cartelized, which are:

a. Ideology as something that is not important in determining the behavior of the party.

b. The parties are permissive or all-inclusive (promiscuous) in forming coalitions.

c. The opposition tends to be non-existent or unidentifiable because it threatens to interfere with the government.

\footnotetext{
${ }^{21}$ Levitsky, S., \& Way, L. A. (2010). Competitive authoritarianism: Hybrid regimes after the cold war: Cambridge University Press.
} 
d. Election results have little or no impact on the behavior of parties.

e. The parties, whether in government or not, tend to affiliate into a large group in dealing with emerging policy issues.

Character number 1 , the ideology as something that is not important in determining the behavior of the party, can be proved by the behavior of Political Parties in the regeneration to determine the candidate leader, either in the Executive Board or Legislative Institution in Banten Province. Political parties are less effective in recruitment and cadre. The Act of 2011 requires the party to play the role of education and regeneration. However, the tendency of the party closed in recruitment. The average party candidates are those who are economically steadily established not the result of a serious recruitment process. ${ }^{22}$ In Golkar Party of Pandeglang Regency for example, this Party is controlled not by Pandeglang people. But by the family of Rau (family of Haji Chasan). Clans and patrons became the pattern used by the Rau family. Hasan Shocib started structurally using the party with his charismatic as Jawara (thugs). Jawara loyal to any risk and Hasan Shohib was able to pay anyone who would sacrifice for the Rau family. The entry through the party took place around the year 2002. Thus Ratu Atut became the definitive governor for about 11 years old. Forming a patron and controlling the bureaucracy. Political party always led his opinion to heavy carry other candidates who are not from the Rau family. ${ }^{23}$

Chasan Shochib's family was traditionally affiliated to Golkar Party, which in the context of Pilkada battle in Banten became a pragmatic party. However, in fact, it is not only Golkar Party that is maintained, any Party that comes to the Ratu Atut family is supported. So, any party such as PBR, PPP finally have a debt to them. Their activists often visit Sukamiskin to visit their money machines. This is one way to maintain the network by controlling other parties with financing support ${ }^{24}$

The dynasty political practice that took place in Banten will continue to undermine democracy in Indonesia and of course in the Pilkada. In addition, the political dynasty has also damaged the form of regeneration of political parties. There is no change even more rampant with the politics of dynasties in Indonesia, even political parties do not care about the background of its politicians, which is important only enough logistics for the campaign. This means that political party becomes very pragmatic in Banten province. There are many loopholes that can be used by political parties to continue to perpetuate dynastic politics or kinship politics. None of the Election and Election Laws limits the nomination requirements of the Regional Head based on family relations.

Thus, if a family has unlimited financial resources, then they have a great opportunity to play the political party as a

22 FGD Result, Politik Kekerabatan dan Dinasti Politik dalam Pemilihan Gubernur Banten, Universitas Mathla'ul Anwar Banten, July 29, 2017

${ }^{23}$ Idem

${ }^{24}$ Opcit vehicle to advance in the contestation of the Regional Head Election. Even up to the Seven Mountains is not a problem because legally this is not prohibited. Judicial Review to the Constitutional Court about this restriction was rejected by the institution. This is one of the major jobs in the context of the regeneration of Political, Recruitment and Democracy in Indonesia.

\section{Kinship Political Instrument}

There are many interesting facts that the great family of Ratu Atut Chosiyah has been so superior in Banten due to the direct intervention of political party. In 2002, Atut was elected to be the Vice Governor with Djoko Munandar who was supported by the Golkar faction and the PPP faction. In the 2006 elections, Ratu Atut Chosiyah, who was paired with HM Masduki, won the Pilkada Banten with support from Golkar, PDI-P, PBR, PBB, PDS, Patriot Party and PKPB. Then in 2011, Atut re-set as the winner by the KPUD Banten paired with Rano Karno with support from the Golkar Party, PDI-P, Hanura, Gerindra, United Nations, PKB, PAN, Nahdlatul Ummah Persatuan Indonesia Party, United Nations Concerned Party, Regional, Prosperous Peace Party, and supported by 22 non-parliamentary political parties.

In 2008, Bunyamin who was paired with Tubagus Haerul Jaman (Ratu Atut's sister from stepmother), won the election of the Mayor of Serang supported by Golkar Party, in 2013, Tubagus Haerul Jaman in pairs with Sulhi Choir again won the Serang election. The party that supports the two as written by Tempo on June 10, 2013 are 12 parties named Coalition Madani, namely Golkar Party, Democratic Party, PKB, PPP, PKS, Partai Nahdlatul Umat (PNU), Partai Bintang Reformasi (PBR), PKP Indonesia, Gerindra Party, Republican, PNI Marhaenisme and the Indonesian Workers Entrepreneurs Party (PPPI).

The facts above show that the main instrument used by the Ratu Atut Family to perpetuate their Family Politics is by "holding" the Political Party in Banten Province. Even with the arrogance of the Great Family of Ratu Atut dare say that they are bigger than the Political Party, because under any conditions Political Kinship they can still play with once again take advantage of Political Party is very Pragmatic. ${ }^{25}$ It happens because the constitution does give the gap of the kinship politics.

The second instrument is to utilize the bureaucracy. Among bureaucrats for example in Lebak there is a briefing to select a particular candidate. The role of jawara and ulama is very significant here. There is pressure on bureaucrats through promotion or mutation to bureaucrats. In the event of bureaucracy, keep the distance. At the top leader level, top leaders play a more important role in rents.

Not only using the instruments of political parties and bureaucracy alone, the Ratu Atut family also take advantage of the condition of rural communities those are very

${ }^{25}$ FGD Result, Politik Kekerabatan dan Dinasti Politik dalam Pemilihan Gubernur Banten, Universitas Mathla'ul Anwar Banten, July 29, 2017 
pragmatic. Indeed, based on research conducted by Fatih $^{26}$, the character of the Banten community is divided into three parts, namely the pragmatism of rural communities, urban apathy and enlightened communities. In the countryside the community is very pragmatic even very acute. At the rural level, kyais are no longer cultural brokers but political brokers, who are able to influence the preferences of the villagers' preferences.

\section{E. Conclusion}

Political practice of kinship has rapidly grown in Banten elections that originated from the family of Tubagus Chasan Sochib, which is, then, followed by the family of Jayabaya and Iskandar. Political practice of kinship is emerging and well spreading in Banten because of strong patron-client pattern of leadership. In addition to the low social control due to the relatively low level of education of Banten society. Political kinship will always be growing unless there is strong effort to increase the enlightened society group who effectively control the governance.

\section{Reference:}

Agustino, Leo, dan Mohammad Agus Yusoff, Politik Lokal di Indonesia: dari Otokratik ke Reformasi Politik, in Jurnal Ilmu Politik, Edition of 21, 2010.

Casey, Kimberly Lynn, Family Matters: The Prevalence and Effects of Political Families in National Politics, Disertasi, University of Misouri, 2009.

De Votta, Neil, Srilanka: From Turmoil to Dynasty, dalam Journal of Democracy, Vol. 22, No. 2, April 2011.

Djati, Wasisto Raharjo, Revivalisme Kekuatan Familisme dalam Demokrasi: Dinasti Politik di Aras Lokal, in Jurnal Sosiologi MASYARAKAT, Lab Sosio Universitas Indonesia, Vol. 18. No 2. July 2013, hal. 181-231.

Eriyanto, Dinasti Politik dalam Pilkada: Menguntungkan atau Merugikan Kandidat? (Kasus Pilkada Kabupaten Kediri), in Jurnal Ilmu Pemerintahan, Edition of 36, 2012, MIPI, Jakarta.

Liddle, William, Partisipasi dan Partai Politik di Indonesia Awal Orde Baru, Pustaka Utama Grafiti, Jakarta, 1992 ,

Querubin, Pablo, Political Reform and Elite Persistence: Term Limits and Political Dynasty in the Philippines, Harvard Academy for International and Area Studies, October, 2011

Romli, Lili, Jawara dan Penguasaan Politik Lokal di Provinsi Banten 2001-2006, Disertation, Pasca Sarjana Ilmu Politik Universitas Indonesia, 2008.
Smith, Daniel Markham, Succeeding in Politics: Dynasty in Democracies, Disertation, University of California, 2012.

Zuhro, R. Siti. Demokrasi Lokal, Peran Aktor dalam Demokratisasi, Penerbit Ombak, Yogyakarta, 2009.

I. 